\section{LA RESTRICCIÓN AL DERECHO DE INDEMNIZACIÓN DEL DAÑO ANTIJURÍDICO, ENTRE LA LEGITIMI- DAD LEGISLATIVA Y EL CONTROL JUDICIAL A LA ADMINISTRACIÓN*}

\author{
Juan Pablo Sarmiento Erazo ${ }^{* *}$ \\ Universidad Javeriana
}

Fecha de recepción: 30 de abril de 2009

Fecha de aceptación: 25 mayo de 2009

\section{Resumen}

A partir de la investigación realizada desde la jurisprudencia constitucional y administrativa colombiana, que da lugar al debate entre derecho a la propiedad, regulación y expropiación, se argumenta que, la voluntad del legislador puede extraerse de maneras más o menos favorables a los derechos patrimoniales individuales, y la manera en que la justicia administrativa y constitucional intervienen para ponderar, mediar o privilegiar la voluntad del órgano de representación. Se cuestiona entonces la legitimidad y legalidad de la intervención del juez administrativo, que no actúa como juez constitucional, para condenar al Estado por la restricción o la vulneración del derecho de propiedad de los asociados de normas pre y post interpretadas constitucionalmente.

\section{Palabras clave}

Leyes expropiatorias, responsabilidad del Estado legislador, regulación, cesiones obligatorias gratuitas, democracia deliberativa, legitimidad de los jueces.

* El presente artículo es producto de la investigación adelantada por el autor sobre la legitimidad y legalidad de la intervención del juez administrativo desde la perspectiva jurisprudencial, constitucional y administrativa.

** Abogado de la Pontificia Universidad Javeriana, Magíster en Derecho de la Universidad de los Andes y cursa sus estudios de Doctorado en Derecho en la misma universidad. Profesor del Departamento de Historia y Filosofía del Derecho de la Pontificia Universidad Javeriana, profesor y asesor en proyectos de investigación en Derecho Administrativo y responsabilidad del Estado en la Universidad de Andes.

\section{RESTRICTION OF THE RIGHT TO COM- PENSATION OF DAMAGE UNLAWFUL, BETWEEN THE LEGITIMATE LEGIS- LATIVE AND JUDICIAL CONTROL OF THE ADMINISTRATION}

\begin{abstract}
Based on research conducted since the constitutional and administrative law in Colombia, leading to the debate between property rights, regulation and expropriation, it is argued that the legislature will be drawn in more or less favorable to individual rights and how the constitutional and administrative justice act to balance, or privilege will mediate the representative body. Then questioned the legitimacy and legality of intervention by the administrative law judge, who does not act as a constitutional judge, to condemn the State for the restriction or infringement of the rights of property of the associated pre and post rules interpreted the Constitution.
\end{abstract}

\section{Keywords}

Expropriatories Laws, responsibility of the State Legislature, regulatory squeeze free, deliberative democracy, legitimacy of judges

\section{INTRODUCCIÓN}

El objetivo de este escrito consiste en demostrar cómo el juez administrativo puede llegar a transformar la voluntad del legislador, cuando declara la responsabilidad de esta rama del poder público. Este supuesto nace de la tensión que persiste entre la voluntad expresa o implícita del legislador de limitar o impedir el reconocimiento de indemnización por los daños causados por la ley y el derecho a ser reparado por daños antijurídicos causados al asociado.

Esta manifestación se sostiene desde nuestro sistema jurídico, en el cual, el Tribunal constitucional es el único juez competente para conocer de la constitucionalidad de una ley, de manera que el juez administrativo no podría aportar de forma alguna, elementos normativos que tanto la Corte como el Legislador, han excluido de la regla. Con todo, si el juez administrativo reconoce la indemnización a un particular afectado por la disposición, 
y el legislador se ha opuesto expresa o tácitamente a la misma, ¿es legítima la providencia judicial?, y en caso positivo, ¿nos encontramos frente a una forma de reparación de un patrimonio contrademocrático o tan sólo se trata de la intervención del juez administrativo en el "proceso dialógico"'?

Entonces, expondremos cómo la Corte Constitucional colombiana ha partido de la oposición a la indemnización en escenarios expropiatorios en consideración al interés general de la sociedad, para realizar giros jurisprudenciales que reconocen la permanente afirmación de la justa indemnización. Así mismo, señalaremos el espacio, que desde nuestra experiencia, permite al Juez administrativo asumir competencia para conceder la indemnización en eventos expropiatorios o de oposición a la reparación en la Ley por un daño causado por el mismo Estado Legislador.

Con este propósito, presentaremos los diferentes grados de oposición del legislador que legitiman o impiden por completo, el reconocimiento a la justa indemnización. Así, nos referiremos primeramente a la oposición implícita del Legislador al derecho de reparación que puede permitir un papel activo del juez administrativo (1.), para luego, exponer el problema de la oposición expresa del Legislador al derecho a la indemnización (2.), y así, tratar la dificultad proveniente de las leyes expropiatorias (3.), para recapitular los temas tratados en el marco de la experiencia nacional (4.). Finalmente, expondremos brevemente el papel del juez administrativo en la configuración del sistema jurídico democrático por medio del proceso dialógico (5).

\section{OPOSICIÓN IMPLÍCITA DEL LEGISLADOR AL DERECHO DE REPARACIÓN Y EL PAPEL ACTIVO DEL JUEZ ADMINISTRATIVO}

Desde la experiencia española, se ha entendido que la atribución del Tribunal Supremo para

GARGARELA, Roberto, ¿Democracia deliberativa y judicialización de los derechos sociales?, conferencia del 29 de Septiembre de 2006. declarar la indemnización por causa de una ley, puede producir una injerencia directa en el contenido mismo de la norma y en consecuencia, de la libertad de configuración del Legislador, donde la eficacia de su producto normativo queda condicionada por decisiones judiciales eventuales y aisladas ${ }^{2}$.

Así, en el ordenamiento constitucional español, el poder de decidir la constitucionalidad de una ley corresponde exclusivamente al Tribunal Constitucional, razón por la cual, la doctrina de ese país ha entendido que sólo este Tribunal tiene la competencia para declarar la Constitucionalidad de la disposición, que dados los efectos diferidos en el tiempo o la modulación propia de la sentencia, podemos derivar directamente la reparación de un daño generado por la decisión legislativa ${ }^{3}$.

Luego, la imputación de responsabilidad puede acercarse a la sustitución de voluntad del legislador, en el entendido en el que la constitucionalidad de una ley la define exclusivamente el juez de constitucionalidad, y estando el Tribunal contencioso administrativo obligado a proyectar su decisión, basado en una disposición de la Carta Fundamental, podríamos aceptar la hipótesis anteriormente planteada.

La principal objeción que se presenta a la reparación patrimonial resulta ser la voluntad popular, entendiendo que la ley es la expresión de voluntad del pueblo deduciendo que la imputación de responsabilidad y consecuente declaración reparativa tendrá por resultado poner en cuestión las "bases mismas del Estado Democrático"4.

GARCÍA DE ENTERRÍA, Eduardo. La Responsabilidad Patrimonial del Estado Legislador en el Derecho Español, Ed. Thomson Civitas, Madrid 2005. p. 119.

3 Sobre los efectos patrimoniales de las sentencias de inconstitucionalidad, ver HERNÁNDEZ VALLE Rubén, La tipología de las sentencias constitucionales con efectos fiscales, Revista Española de Derecho Constitucional, Año 14. Núm. 41. Mayo-Agosto 1994.

4 GARCÍA DE ENTERRÍA, Eduardo. Democracia, jueces

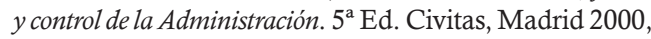
p. 211. cita a J- GUASP Aragoneses, Derecho Procesal

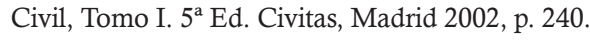


En idéntico sentir, la práctica Alemana reprueba la intervención judicial con el objeto de remediar el daño producido por la aplicación de una ley. Precisamente, la Ley alemana de 1981 en su artículo 5.2 establece que la responsabilidad del Estado, por la adopción de actos legislativos, se produce ante un comportamiento antijurídico "sólo cuando y en la manera que la ley lo determine". Lo anterior ha permitido que la doctrina de ese país interprete, ante el silencio de la ley respecto a la indemnización, que esta reserva equivale a su negación. De este modo, ante el silencio del legislador, no existe forma alguna de declarar la indemnización a favor del patrimonio del individuo perjudicado ${ }^{5}$.

Por su parte, la experiencia francesa parecería basar la construcción de la responsabilidad del Estado Legislador en la interpretación de la voluntad del legislador, o de los trabajos preparatorios de la norma generadora del daño especial. Desde sus inicios, observamos el arrét Ferrier de 6 de agosto de 1852, en el que se rechazó la demanda de indemnización por los daños causados por la supresión de la telegrafía privada, realizada por la Ley de 2 de mayo de 1837; en el arrét Moroge, del 5 de febrero de 1875, el Consejo de Estado francés negó el pago de compensaciones a un fabricante por los daños producidos por la Ley del 2 de agosto de 1872, creadora del monopolio de cerillas; y en el arrét Compagnie Algerienne, del 7 de diciembre de 1894, se negó cualquier reconocimiento de los daños producidos a esta empresa, por el reembolso de cantidades adelantadas al Estado, ordenado por la Ley presupuestaria de 26 de diciembre de 1892. Luego de mantener esta línea, la interpretación de la voluntad tácita del legislador toma mayor fuerza con el arrét Société Premier Et Henry del 29 de abril de 1921, donde se argumentó que la Ley del 16 de marzo de 1915 tenía la exclusiva finalidad de impedir la elaboración de produc-

MAYER O. Derecho Administrativo Alemán, $2^{\mathrm{a}}$ Ed., Buenos Aires, Depalma 1992, p. 237. y FORSTHOFF Tratado de derecho Administrativo, Ed. Instituto de Estudios Políticos, Madrid 1958, Citados por ALONSO GARCÍA Consuelo, Op. Cit.. p. 122. tos peligrosos para la salud pública, como la fabricación de ajenjo (bebida fermentada peligrosa para la salud), y no ha previsto indemnización alguna en favor de los industriales cuyos intereses se vieron afectados por la prohibición antedicha, resultaba en todo caso, excluida implícitamente por el mismo legislador ${ }^{6}$.

El arrét La Fleurette permitió sostener y cerrar esta posición jurisprudencial al aseverar, como requisito de la indemnización, "que nada, ni en el texto mismo de la ley ni en sus trabajos preparatorios, ni en el conjunto de las circunstancias del asunto permite pensar que el legislador ha querido hacer soportar al interesado una carga que no le incumbe normalmente; que esta carga, impuesta en interés general, debe ser soportada por la colectividad; que de ello se sigue que la sociedad 'La Fleurette' tiene derecho a exigir que el Estado sea condenado a abonarle una indemnización en reparación del perjuicio por ella sufrido"7. Sin embargo, este fallo se aleja de su precedente en el sentido en el que el "silencio de la ley sobre la indemnización no constituye una presunción iuris et de iure sobre la exclusión del resarcimiento, sino una presunción iuris tantum que puede ser destruida mediante la prueba contraria de que el legislador no pretendió evitar la indemnización" ${ }^{8}$. En todo caso, la práctica francesa excluye el derecho a indemnización cuando el acto normativo dañoso recae sobre una actividad riesgosa, inmoral, ilícita o contraria a la sanidad nacional o al orden público.

En desarrollo de este argumento, la experiencia española considera que una decisión judicial diferente significaría la desnaturalización radical del papel del juez administrativo, que se vería investida de un poder normativo directo frente a

\footnotetext{
SANTAMARÍA PASTOR, Juan Alfonso. La teoria de la responsabilidad del Estado legislador, Revista de Administración Pública, Num. 68, Mayo-Agosto de 1972, p. 72 y 79.

7 BROYELLE, Camilla. La responsabilité de L'état du fait des lois, Librairie Générale de Droit et de Jurisprudence, Bibliothèque de droit Public Tome 236, 2003. p 73.

8 SANTAMARÍA PASTOR, Juan Alfonso. Op. Cit. p. 88.
} 
la representación popular9. Lo anterior, basado en que, primero, los Tribunales Administrativos tienen el deber de controlar la potestad reglamentaria, mas no, considera el profesor García de Enterría, de la potestad legislativa.

Segundo, el Juez controla la legalidad de los actos de la Administración, es decir, examina que la administración actúe en cumplimiento de la 1 ley ${ }^{10}$, limitando por completo la posibilidad del Tribunal Administrativo de declarar patrimonialmente responsable al legislador, por la falta del servicio o excesos que conduzcan a la inconstitucionalidad de la norma y eliminando enteramente, la capacidad del juez de controlar omisiones legislativas.

Como podemos notar, estos puntos resultan bastante discutibles, sin embargo, pese a que en este documento lo debatiremos a profundidad, podemos adelantar la siguiente objeción. El juez administrativo se encuentra vinculado a la Constitución, la cual no sólo tiene por atributo la supremacía sobre los demás poderes públicos, sino que goza de supralegalidad, condición que supone la normativización de las disposiciones constitucionales que tiene por efecto, el despliegue de reglas constitucionales, pre o pos interpretadas por el Tribunal Constitucional, a supuestos de hecho que, dado el caso, requieran la reparación directa del patrimonio del particular.

En la experiencia española, se ha señalado que la misma Carta Fundamental no admite que el Tribunal administrativo impute responsabilidad al legislador porque el cuerpo de representación prevé que sus productos normativos pueden tener consecuencias negativas no deseadas ${ }^{11}$. Esto supone entonces que la Constitución impone un sometimiento pleno, exclusivo e incluso a la Ley, entendida ésta como único producto del legislador soberano.

\footnotetext{
$9 \quad$ GARCÍA DE ENTERRÍA, Eduardo. La Responsabilidad Patrimonial del Estado Legislador en el Derecho Español. Op. Cit., p. 124.

10 Ibidem.

11 Ibid.
}

\begin{abstract}
Ahora bien, en este punto, el cual disentiremos posteriormente en este escrito, rechazamos desde ya la comprensión estricta del concepto de ley, pues tratándose la Constitución de una supra norma, ésta tiene eficacia directa en todas las decisiones de los poderes públicos, lo que implica por demás, seguir de cerca el artículo 9.3 de la Constitución Española ${ }^{12}$, disposición que establece la cláusula general de responsabilidad del Estado, y en el caso español, inhiben toda actuación "arbitraria" de los poderes constituidos.
\end{abstract}

En el mismo sentido, podemos presentar una crítica dirigida a una lectura incompleta del artículo 9.4 de la Ley Orgánica del poder judicial ${ }^{13}$, pues éste establece que la administración es imputable "sea cual sea la naturaleza de la actividad o el tipo de relación que se derive". En este sentido, el Legislador español ha sido explícito, "la Administración Pública, sea cual sea la actividad que desarrolle, es imputable y la jurisdicción contencioso administrativa es competente para conocer de su responsabilidad patrimonial, sin que esto implique la sustitución de su voluntad"14.

La respuesta a la antepuesta posición resulta debatida por el autor García de Enterría, quien ha señalado que la misma ley trae la "inequívoca" restricción a la competencia del juez administrativo, consistente en el control a "las disposiciones generales de rango inferior a la Ley". De modo que, considera, resulta "expresa" la limitación a cualquier jurisdicción para cuestionar las leyes propiamente dichas. En este razonamiento, sólo serían censurables aquellas regulaciones "internas" del órgano legislativo $\mathrm{y}$ en sus relaciones económicas con terceros

12 Ver también QUINTANA LÓPEZ, Tomas. La responsabilidad del Estado legislador, Revista de Administración Pública, Num. 135, septiembre-diciembre 1994. p. 130.

13 Dice el artículo citado: Conocerán asimismo, de las pretensiones que se deduzcan en relación con la responsabilidad patrimonial de las Administraciones Públicas y del personal a su servicio, sea cual sea la naturaleza de la actividad o el tipo de relación que se derive.

14 FERNÁNDEZ, Tomás-Ramón. De la Arbitrariedad del Legislador, una crítica de la jurisprudencia Constitucional, Ed. Civitas Madrid 1998, p. 41 y ss 
como sujeto de derecho, resultando excluida toda expresión "genuina del poder legislativo y en cuanto representantes del pueblo para regir a la comunidad política respectiva" ${ }^{15}$.

Esta respuesta sólo asienta la continuación del argumento previo, en la medida en que la jurisdicción contencioso administrativa parecería competente para conocer de la responsabilidad patrimonial del Estado Legislador, no sólo por tratarse de la competencia que le otorga la Ley Orgánica del Poder Judicial español, sino porque el mismo Tribunal Constitucional Español así lo ha entendido. Con todo, la Justicia Constitucional lo desplegó desde la limitación de los poderes públicos hacia la arbitrariedad ${ }^{16}$, elemento igualmente válido, lo que por su parte demuestra la supralegalidad de la Constitución, permitiendo a su vez, de su aplicación directa, limitar al legislador y legitimar la intervención del juez administrativo.

Empero, García de Enterría modera un poco las limitaciones antepuestas en cuanto reconoce que es posible imputar responsabilidad en el Legislador, cuando "no haya que forzar la interpretación del precepto para comprender la responsabilidad por actos legislativos". De esta manera, pese a que no le resultó fácilmente admisible, puede aceptar, siempre que sea una interpretación estricta de la norma, la reparación patrimonial individual ante silencios normativos ${ }^{17}$. Lo anterior claro está, con el objeto de encontrar esa voluntad implícita del Legislador que permita, por decirlo de alguna manera, "autolimitarse".

En este punto propondríamos una importante réplica, el autor citado ha deducido la necesaria

15 Ibidem., p. 131.

16 Ibid., p. 43, Cita entre otras sentencias del Tribunal Constitucional Español: STC del 20 de julio de 1981, STC del 19 de julio de 1982, STC del 23 de mayo de 1985, STC del 29 de julio de 1986, STC del 11 de junio de 1987, STC del 22 de marzo de 1988, STC del 29 de Noviembre de 1988, STC del 22 de Abril de 1993, STC del 22 de junio de 1993.

17 GARCÍA DE ENTERRÍA, Eduardo. La Responsabilidad Patrimonial del Estado Legislador en el Derecho Español p. 138. interpretación estricta de la norma para imputar responsabilidad en el Legislador de su propia voluntad, lo que supone que el legislador prevería el daño que ha de causar su decisión normativa, permitiéndonos considerar la idea de inconstitucionalidad de la norma, pues si desde la formación de la ley, el legislador prevé el daño anormal a un patrimonio particular, podríamos estar ante la violación al derecho de igualdad. Esto considerando que una norma es general y abstracta y la previsión de daños particulares podría suponer la intención directa del legislador de causarlos.

Finalmente, una solución plausible es la propuesta por la práctica argentina al evaluar la constitucionalidad de una norma. Entiende la Corte Suprema de Justicia de ese país que en materia de interpretación de las leyes, debe preferirse la que mejor concuerde con "las garantías, principios y derechos consagrados en la Constitución Nacional. De manera que solamente se acepte la que es susceptible de objeción constitucional cuando ella es palmaria y el texto discutido no sea lealmente susceptible de otra concordante con la Carta"18.

En idéntico sentido, la experiencia española puede aportar una luz a este método. Así, entiende que es principio general, en materia constitucional, aquella interpretación de la ley que sea conforme a la Constitución, y se debe rechazar aquel que innecesariamente conduzca a su contradicción con la Carta fundamental. No obstante, su afirmación ha sido bastante estricta, evidente al momento de categorizar la naturaleza de la función de control constituciona $1^{19}$.

18 MENDONCA, Daniel y GUIBOURG, Ricardo. La Odisea Constitucional, Ed. Marcial Pons, Ediciones jurídicas y sociales, Madrid 2004. p. 166

19 SALAS. Javier. El tribunal constitucional español y su competencia desde la perspectiva de la forma de gobierno: sus relaciones con los poderes legislativo, ejecutivo y judicial, Revista Española de Derecho Constitucional. Abril 2. Núm. 6. Septiembre-diciembre 1982. Cita la sentencia del $1^{\circ}$ de junio de 1981 (A. 231/1980). "La ley, como emanación de la voluntad popular, sólo puede ser en principio derogada o modificada por los representantes de esa voluntad, y sólo para el caso de que el precepto legal infrinja la Constitución se ha concedido a este Tribunal potestad de anularla. Esta potestad sólo puede 
Ambas prácticas logran exponer una forma de legitimar y preservar competencia en el juez administrativo para la imputación de responsabilidad, pese al silencio legislativo. El juez administrativo examinará la norma excluyendo toda oposición implícita del legislador a la reparación patrimonial, cuando ésta resulte contraria a la disposición constitucional, de manera que la reparación solicitada por el individuo afectado por la decisión legislativa resulta de la misma interpretación y seguimiento a la Ley, desde la integración con la disposición constitucional.

De este modo, no resulta muy apropiado buscar la voluntad implícita del legislador por medio de interpretaciones estrictas de la Ley generadora del daño, con mayor razón, cuando el texto es preinterpretativo, pues como hemos visto en el desarrollo de este documento, el texto postinterpretado por el Tribunal Constitucional, facilita la imputación de responsabilidad en el Legislador. Lo que podría resultar adecuado es la búsqueda directa en la Constitución, de elementos tales como: la garantía al derecho de propiedad y expropiación con indemnización, derecho a la igualdad, principio de buena fe (seguridad jurídica y confianza legítima), y demás garantías que la Carta consagra a favor del individuo y de los cuales, podríamos suponer, han sido consultados, o incluso desarrollados por el Legislador.

Nuestra experiencia parece menos agitada, en la sentencia C-038 de 2006, la Corte Constitucional Colombiana ${ }^{20}$, la cual decide justamente

ser utilizada, sin embargo, cuando así lo exigen razones muy graves y sólidas; cuando un órgano constitucional o parte sustancial de él afirman la existencia de esa infracción, o cuando, de no ser declarada dicha infracción, un órgano judicial hubiera de verse en la situación de violar la Constitución porque, estando sometido al imperio de la ley (art. 117.1 de la Constitución), carece de facultades para inaplicarla, aunque la considere contraria a una norma mas alta, pero anterior en el tiempo. Cuando estas razones sólidas y graves no existen, el respeto del legislador exige que este Tribunal se abstenga de hacer pronunciamiento alguno".

20 Magistrado Ponente: Humberto Antonio Sierra Porto. Sentencia que declara la constitucionalidad del artículo 86 del código Contencioso administrativo que dispone: "Acción de reparación directa. La persona interesada po- sobre la constitucionalidad de la omisión legislativa del artículo 86 del Código Contencioso administrativo, acusada por no contemplar explícitamente la responsabilidad del Estado legislador, ha expresado que:

Dejando a un lado la cuestión sustancial del fundamento de la responsabilidad patrimonial estatal, cabe destacar que en todos los anteriores casos la acción impetrada fue la de reparación directa, de lo que se deduce que de conformidad con el máximo órgano de la jurisdicción contencioso administrativa esta es la vía judicial procedente para reclamar la reparación de los daños antijurídicos imputables al hecho del legislador.

Esta sentencia señala la interpretación abierta de Administración Pública, entendiendo que este significante incluye al Estado Legislador. Así mismo, encontramos un proceso argumentativo inverso al realizado por el Tribunal Constitucional español, pues como recordamos, éste acudió a la Constitución para inhibir actuaciones arbitrarias de cualquier rama del poder público, mientras que la Corte Constitucional consideró al artículo 86 del Código Contencioso administrativo como aquella cláusula general de competencia de la jurisdicción Contenciosa administrativa, debiendo quizá, acudir a la misma Constitución para legitimar y reconocer la competencia del Consejo de Estado.

La voluntad popular es construida desde el artículo $3^{\circ}$ de nuestra Constitución ${ }^{21}$, partiendo

drá demandar directamente la reparación del daño cuando la causa sea un hecho, una omisión, una operación administrativa o la ocupación temporal o permanente de inmueble por causa de trabajos públicos o por cualquiera otra causa (...)". Se debate si el Congreso incurrió en una omisión legislativa relativa que desconocería el artículo 90 de la Constitución Política, al no contemplar expresamente entre dichos supuestos, los hechos y omisiones imputables a la actividad del Estado Legislador.

21 Ver Corte Constitucional Colombiana, Sentencia C245 de 1994, Providencia donde la Corte desprende la voluntad popular desde el artículo $3^{\circ}$ de la Carta y en consecuencia, la soberanía retenida y delegada del poder popular al Legislador así "El Constituyente de 1991 introdujo, en el artículo 3o. de la Carta Política un cambio de profundas implicaciones tanto políticas como consti- 
de dos condiciones. La primera, la voluntad popular en nada sugiere amparar la voluntad implícita del legislador de privar al particular de derechos adquiridos sin indemnización justa, pues el mismo constituyente en el artículo 58 de la Carta, reformado a partir de 1999, no permite la privación de derechos legítimamente adquiridos sin indemnización previa y el artículo 336 impide la ejecución de leyes que priven a particulares de actividades económicas, hasta que no sean indemnizados quienes hayan estado ejerciendo la actividad restringida.

La segunda condición conduce a que el control contencioso de leyes y la responsabilidad del Estado parecerían instituciones que, de la mano de normas constitucionales inmediatamente citadas, impiden que el desarrollo del interés general subordine intereses particulares, los cuales resultan protegidos desde la misma Carta fundamental, de manera que la interpretación de una ley no puede buscar la voluntad implícita del legislador contraria a la Constitución, tal interpretación sería inconstitucional.

Aunado a lo anterior, la supralegalidad de la que goza nuestra Constitución impide que alguna interpretación de la ley pueda ser contraria a su composición, de manera que el juez constitucional y el administrativo siguen a la Carta como norma y en este sentido, desde el artículo 58 y 336, la privación de derechos patrimoniales supondrán siempre el reconocimiento de una indemnización y no otra interpretación al silencio de la Ley.

tucionales, al establecer que "la soberanía reside exclusivamente en el pueblo, del cual emana el poder público". Igualmente, en el artículo 133 estableció que "los miembros de los cuerpos colegiados de elección directa representan al pueblo y deberán actuar consultando la justicia y el bien común". Este mismo artículo agrega: "El elegido es responsable politicamente ante la sociedad y frente a sus electores, del cumplimiento de las obligaciones propias de su investidura". Dicho cambio implica, ni más ni menos, que la adopción del concepto de "soberanía popular" y, por ende, la sustitución del concepto de "soberanía nacional" que en la tradición constitucional colombiana venía figurando desde las primeras constituciones de la República y que la de 1886 consagraba también, en su artículo 2o.: " $L a$ soberanía reside esencial y exclusivamente en la Nación...".
El artículo 90 de la Constitución impone además que todo daño causado al individuo debe ser indemnizado partiendo de la actuación y la omisión del Estado, que desde la sentencia C-038 de 2006, supone también al Legislador, de modo que si existe interpretación en que de alguna manera se acepte una norma que implícitamente se opone al reconocimiento de indemnizaciones, será el juez administrativo el que por vía de la reparación directa, restaure el patrimonio privado afectado interpretando la Carta como norma vinculante directamente en ese caso concreto.

No obstante, existen dos maneras de limitar esta aparentemente amplia restricción a la oposición implícita a la indemnización por parte del Legislador. Primera, no puede repararse la restricción de actividades privadas intrínsecamente ilícitas, las cuales serán tratadas a continuación, debido a que en experiencias foráneas y nacionales, parece común encontrar la oposición expresa a la reparación por parte del Legislador, porque las actividades que restringen suponen actividades dañosas o muy riesgosas que pueden generar perjuicios a la sociedad en conjunto o a particulares.

Este evento permitiría a ambos jueces, administrativo y constitucional, descubrir la voluntad implícita del legislador en oponerse a cualquier reparación. Luego, del desarrollo de toda ley a la voluntad y el interés general, el particular que desarrolle la actividad prohibida no podría solicitar la reparación del daño causado por la actividad vedada.

El segundo límite a la restricción de oposiciones implícitas consiste en la diferenciación entre regulación de un derecho y su privación. La regulación supone restricciones que dirigen la actividad económica o la explotación de derechos de propiedad a lo que se considere más conveniente al interés general. La privación del derecho de propiedad implica la desaparición del derecho de propiedad o de la actividad económica, lo que a la luz de nuestra Constitución, supone la constante reparación del patrimonio mediante la expropiación y en ocasiones, como 
lo veremos en este estudio, de la indemnización por vía de reparación.

\section{OPOSICIÓN EXPRESA DEL LEGISLADOR A LA REPARACIÓN}

Desde la experiencia española, el autor Jiménez Lechuga encuentra como principal objeción a la reparación del daño patrimonial particular, la disposición expresa del Legislador que impida su reconocimiento ${ }^{22}$. Este autor intenta objetar la señalada postura atendiendo a una equivocada formulación del argumento, debido a que intenta configurar desde la expropiación, la responsabilidad del Estado por los actos del legislador con objeción expresa al resarcimiento de los daños pueden ser restaurados no por vía de expropiación sino de la reparación.

Esta reformulación presentada por Jiménez parece muy técnica y quizá innecesaria, con mayor razón cuando la Constitución española garantiza la propiedad y la expropiación con justa indemnización, además de la ya mencionada inhibición a la arbitrariedad de los poderes públicos. Su argumento toma fuerza cuando se refiere a los "valores superiores" de la justicia y la igualdad (Art. 1.1, 9.2, 10 y 14 de la constitución española), entendiendo que la explícita exclusión de indemnización por el legislador conduce a la contradicción del "espíritu" de los mencionados valores ${ }^{23}$.

En este sentido, aceptar una disposición legislativa así, sería admitir una norma contraria a valores constitucionales, llamado "arbitrario inconstitucional" generadora de daños anormales a los individuos. Tanto más si se tiene en cuenta que los particulares siempre podrán demandar por la tutela efectiva de sus derechos ante la jurisdicción ordinaria ${ }^{24}$.

22 JIMÉNEZ LECHUGA, Francisco Javier. La responsabilidad patrimonial de los poderes públicos en el derecho español, Marcial Pons, Ed. Jurídica y social, Madrid 1999. p. 55.

23 bídem. p. 70.

24 Ibíd., Recuérdese que el sistema jurídico español consagra sólo dos altas Cortes, El Tribunal Constitucional y el Tribunal Supremo. El Consejo de Estado se razonó
Parecería ésta una defensa sólida y jurídicamente acertada, en el entendido en el que las disposiciones constitucionales permiten al juez administrativo la reparación de un patrimonio injustamente causado, o mejor, inconstitucionalmente afectado. Sin embargo, la hipótesis pierde aplicación parcialmente cuando, como lo señaló León Duguit ${ }^{25}$, el Legislador ha impedido o restringido una actividad que hasta ese momento era libre, porque la considera peligrosa o perjudicial para otros sujetos de derecho o para el interés general. En este escenario, la prohibición de una actividad hasta ese momento libre, pero que por su peligrosidad o por los resultados nocivos de la misma, no puede hacer que el Estado incurra en responsabilidad por la prohibición de actividades nocivas, porque el desenvolvimiento de la "solidaridad social", implican que el particular afectado no puede oponerse a la mencionada decisión normativa.

En palabras del profesor Jiménez, se trata del "daño merecido"26, evento en el cual, se perjudica a un particular por aquellos daños que resultasen de la prohibición o limitación de actividades "intrínsecamente" ilícitas y, por tanto, meramente toleradas, pero en modo alguno protegidas.

Este es el caso que podemos tomar de la experiencia francesa. La Ley 13 de 1946 ordenó el cierre de las casas de tolerancia, decisión que legislativamente pronunció que "no habrá lugar a indemnización" 27 , evento en el cual la respon-

como un órgano consultivo de justicia Retenida de la Administración Pública, razón por la cual Jiménez Lechuga habla de un procedimiento ordinario.

25 DUGUIT, León. Manual de derecho constitucional: teoría general del Estado, el derecho y el Estado, las libertades públicas, organización pública; Traducción por José G. Acuña. $2^{\text {a }}$. Ed. Madrid 1926, p. 19 y ss. p. 289.

26 JIMÉNEZ LECHUGA, Francisco Javier. Op. Cit. p. 72. Como ejemplo del daño merecido, este autor menciona entre otros: Cierre de prostíbulos, imposición de medidas protectoras del medio ambiente y de calidad de vida, prohibición de publicidad del tabaco y bebidas alcohólicas, confiscación de bienes ilegítimamente adquiridos o ligados al narcotráfico.

27 LAUBADERE, A. Treité élèmente Droit Administratif, $5^{\text {a }}$ Ed. París 1970, Citado en JIMÉNEZ LECHUGA Francisco Javier, Op. Cit. p. 79. 
sabilidad del Estado se descarta por la "naturaleza de las actividades a las que se afecta".

Incluso, la experiencia francesa al momento de imputar responsabilidad en el legislador sólo es admitida cuando "nada en el artículo mismo de la ley o en las actas preparatorias de las comisiones redactoras, ni en el conjunto de circunstancias del caso" permita "pensar" que el legislador quiso excluir la reparación particular ${ }^{28}$.

Así mismo, esta experiencia foránea entiende que el legislador excluye cualquier reparación cuando la ley busca reprimir actividades fraudulentas o dañosas ${ }^{29}$ o cuando la ley se ha expedido para el desarrollo del interés económico o social $^{30}$, y en general, cuando se trata de regular el mercado y la producción de bienes ${ }^{31}$.

Desde la práctica española, la admisión de responsabilidad cuando existe oposición expresa del legislador al reconocimiento de reparación, conduciría a la sustitución del legislativo por

28 LONG, Marceau. WEIL Prosper, BRAIBANT Guy, DELVOLVÉ P. y GENEVOIS, Los grandes fallos de la jurisprudencia administrativa francesa, Ed. Librería del Profesional, Bogotá 2000. p. 220. Citan la sentencia del 22 de noviembre de 1957, donde la Compañía de navegación Fraissinet es privado por una ley de un beneficio en ejecución del contrato con el Estado. Providencia que niega la indemnización.

29 Ibidem, cita la sentencia del Consejo de Estado Francés del 14 de enero de 1934 en el caso de la Compañía general de pesca, la cual se vio afectada por la limitación a exportaciones fraudulentas de alcohol. Así mismo se cita la sentencia del 6 de enero de 1954, caso de la Manufacturera francesa de armas, donde se solicita reparación de daños causados por el control establecido a la fabricación defectuosa de armas para proteger a consumidores de esasa armas.

30 Ibid, Cita la sentencia del Consejo de Estado francés del 15 de julio de 1949 casa del la Ciudad d'Elbeuf por la congelación del precio del gas. Igualmente se cita la sentencia de la sociedad inmobiliaria del valle de Chevereuse del 14 de marzo de 1975, donde se solicita reparación patrimonial debido al establecimiento del cálculo de las indemnizaciones de expropiación.

31 Ibid, Cita la sentencia del Consejo de Estado francés del 7 de junio de 1940, caso de la Asociación de Comerciantes de Trigo, debido a la prohibición de cotizar distintos tipos de trigos en la bolsa de comercio para evitar que el trigo se viera "sometido a los caprichos de las cotizaciones especulativas". órganos del Poder Judicial, los cuales deben realizar una labor interpretativa necesaria para la aplicación de otras normas legislativas que le brinden soporte ${ }^{32}$.

Nuestra práctica podrá dirigirse a la protección del particular desde el pronunciamiento de la Corte Constitucional, evento en el que si ésta no encuentra razones suficientes para permitir el "daño merecido" declarará la inconstitucionalidad de la norma, porque como lo veremos posteriormente, la Constitución colombiana y la Convención americana de Derechos Humanos impiden expropiaciones sin indemnización previa, razón por la cual debería declarar inconstitucional una norma que prive al individuo del derecho a la propiedad o la libertad de empresa.

Entonces, corresponderá al juez administrativo reparar el daño patrimonial causado cuando el rompimiento de la igualdad ante las cargas públicas, pese a la intervención de la Corte Constitucional, persista a causa de una oposición explícita del legislador a la reparación. Con todo, dicha reparación únicamente se podrá predicar de derechos adquiridos o actividades económicas conforme al orden constitucional y legal, sin que pueda pretenderse la inaplicación de la norma cuando se trate del "daño merecido".

Así mismo, la oposición explícita del legislador no puede conducir a la previsión de daños anormales y especiales, debido a que la vulneración del derecho de la igualdad de particulares ante la ley puede conducir a la declaratoria de inconstitucionalidad de la ley. En otras palabras, el Legislador se pronuncia mediante normas generales y abstractas, la consideración e intencionada generación de daños excluidos de cualquier reparación, cuando se trate de bienes o libertades cuya restricción no se realice por el peligro o perjuicio que producen, genera la vulneración del derecho fundamental a la igualdad.

32 Sentencia del Tribunal Supremo español del 30 de Noviembre de 1992, Citado por ALONSO GARCÍA Consuelo, La responsabilidad Patrimonial del Estado legislador, Marcial Pons, Ed. Jurídicas y políticas, Madrid 1999. p. 52. 


\section{RECONOCIMIENTO Y OPOSICIÓN DEL LEGISLADOR A LA REPARACIÓN EN LAS LEYES EXPROPIATORIAS}

Cuando nos referimos a las leyes expropiatorias estamos remitiéndonos a aquellos escenarios en los que el legislador ha dispuesto la extinción directa del derecho de propiedad privada. En consecuencia, de la aplicación material de una ley expropiatoria que no conceda derecho a indemnización alguna, nos permitiría constatar la generación de un daño que habría de ser declarado por la inconstitucionalidad de la ley ${ }^{33}$. Por tanto, el reconocimiento del derecho de indemnización no se basa tanto en que la ley lo haya dispuesto expresamente, sino que no previéndolo, la lesión que los particulares sufran por aplicación de la ley debe ser indemnizada ${ }^{34}$.

E1 profesor García Álvarez ha entendido que, desde la práctica española, el artículo 33.2 (artículo sobre expropiación) subordina a toda ley, en el sentido en que la norma deberá ser declarada inconstitucional cuando excluya el resarcimiento patrimonial por expropiación, por cuanto una disposición de estas características resultaría contraria al artículo citado. Sin embargo, este supuesto ha encontrado una excepción efectiva importante, consistente en la Ley de Costas de 1988, la cual excluyó cualquier indemnización para los titulares privados del derecho de propiedad sobre la zona marítimoterrestre fuera de la conversión de sus derechos en concesiones administrativas. Al haber sido

33 JIMÉNEZ LECHUGA, Francisco Javier. Op. Cit. p. 81. En este punto, el mencionado profesor cita la sentencia del Tribunal Supremo de 11 de octubre de 1991, donde la empresa Pedro Domecq S.A. pretende la indemnización por los daños sufridos en su volumen de ventas como consecuencia de la aplicación de la ley 30 de 1979, la cual imponía un gravamen sobre bebidas alcohólicas y a partir de 1981 la prohibía. No obstante, la sentencia no concede la indemnización reclamada. Este es el fundamento de Jiménez Lechuga y García de Enterría para entender inconstitucional una disposición de tales efectos.

34 GARCÍA SOLANO, José Eugenio. Responsabilidad patrimonial del Estado legislador y el proceso descolonizador, REDA num 30 de 1981. p. 582. Ver también QUINTANA LÓPEZ Tomás, Op. Cit. p. 116. declarado dicho precepto constitucional, "ni el Gobierno ni los órganos judiciales podrán establecer una indemnización contra legem" 35 .

Con todo, considerar que el control constitucional a normas expropiatorias resulta suficiente para garantizar la aplicación del principio de igualdad ante las cargas públicas, ilegitimando cualquier intervención del Juez Administrativo, demuestra la debilidad más intensa de la experiencia española. Lo anterior supone igualmente, una omisión conceptualmente inexplicable, y es que el examen de constitucionalidad es una evaluación abstracta que no debe entrar en consideraciones sobre el alcance particular o concreto de la norma acusada como inconstitucional.

Para el ordenamiento constitucional colombiano se presentan dos medios específicos que procuran legitimar la intervención del juez Contencioso Administrativo, a saber, la expropiación y el deber de reparar daños antijurídicos causados a particulares. Así, la expropiación legislativa tiene por resultado un precio. Entendiendo que indemnización y precio no son la misma cosa, por lo que debe comprenderse que al momento de su regulación, expropiación y responsabilidad son instituciones distintas y diferenciables ${ }^{36}$.

En nuestro sistema jurídico, la postura anterior tendría parcial cabida, en la medida en que la Corte Constitucional encontraría que la norma acusada es inexequible, por expropiatoria o incluso por afectar el núcleo fundamental del derecho a la propiedad, siempre que la disposición no reconozca ni consagre de modo alguno la posibilidad de indemnizar a la víctima por la privación al derecho de propiedad. Podríamos considerar adecuada la posición anterior, debi-

35 GARCíA ÁlVAREZ, G. La Responsabilidad Patrimonial de los Poderes Públicos, en Derecho Administrativo, Parte Especial, Ed. Civitas, Madrid 1994. Citado por ALONSO GARCÍA Consuelo, Op. Cit. p. 123. Ver también GALÁN VIOQUE Roberto, De la teoría a la realidad de la responsabilidad del Estado legislador, Revista de Administración Pública Núm. 155. Mayo-agosto 2001. p. 293.

36 ACOSTA GALLO, Pablo, La Responsabilidad del Estado-Juez, Ed. Montecuervo S.A. Madrid 2005. p. 30. 
do a que la decisión de la Corte Constitucional repliega toda posibilidad de indemnizar a la víctima siempre que ésta repare el daño antijurídico, razón por la cual el juez administrativo se encuentra impedido para restablecer el patrimonio afectado, por haberlo hecho ya el Juez Constitucional.

Similar respuesta encontraremos en experiencias foráneas, como por ejemplo, la de Estados Unidos, Italia y Alemania, la Corte Suprema, la Corte Constitucional de Karlsruhe y la Corte Costituzionale respectivamente, en donde los altos Tribunales declararán la inconstitucionalidad de la Ley que ignore o se oponga a la justa indemnización ${ }^{37}$.

No obstante, parecería jurídicamente adecuado, acudir a la institución de la reparación y no a la de la expropiación, pues si el Tribunal Constitucional considera que la norma se ajusta a la Carta Fundamental, mal podría el juez administrativo, para el caso de leyes expropiatorias, proyectar su decisión sobre la disposición legislativa y judicial. De este modo, el juez administrativo dará alcance a la restauración del patrimonio afectado desde la reparación del daño antijurídico (Artículo 90 de la Constitución), imputando responsabilidad desde el régimen del rompimiento en la igualdad ante las cargas públicas y ya no en la falla del servicio legislativo.

Nada obsta además, para que el juez administrativo, por vía de reparación directa, reconozca el derecho a ser indemnizado por daños patrimoniales, cuando encuentre que existe oposición a la reparación por el Legislador e incluso por la Corte Constitucional, pues el Consejo de Estado goza de independencia y su construcción del régimen de responsabilidad del Estado es exclusiva y excluyente. Así, si el juez administrativo debe respetar la competencia legislativa y de la Corte constitucional, éstos deben respetar la suya para conocer de la acción de reparación directa y responsabilidad del Estado.

37 GARRIDO FALLA, Op. Cit., p. 284
El problema podría extenderse además desde la desnaturalización de la decisión judicial, partiendo de la inaplicación de la norma declarada constitucional. En nuestra configuración constitucional, parecería acertado replegar cualquier facultad de indemnizar daños patrimoniales cuando el examen de constitucionalidad ha sido superado y la norma es declarada conforme a la Carta, resultando en todo caso la expresa la oposición del Legislador y de la Corte.

De esta manera, la oposición expresa del legislador que es declarada constitucional inhibe cualquier intervención del juez administrativo. Sin embargo, esta situación no parece plausible si partimos de la misma Carta fundamental, cuyos mencionados artículos 58 y 336 impedirían la aceptación de constitucionalidad de leyes expropiatorias que se opongan al reconocimiento de la indemnización.

Aquí hallaríamos la mayor intervención y activismo del Juez administrativo en la corrección de decisiones Legislativas y de la Corte Constitucional contrarias a la Carta Fundamental. De esta manera, desde la competencia que la Constitución confía en el Juez administrativo, la reparación particular se logra mediante la responsabilidad del Estado por el daño especial y anormal, y ya no desde la expropiación, pues esta vía resultó, desde nuestro caso, descartada.

\section{LA EXPERIENCIA COLOMBIANA, LA PONDERACIÓN VARIABLE ENTRE INTERÉS GENERAL Y DERECHO A LA PROPIEDAD}

La jurisprudencia de nuestra Corte Constitucional parecería bastante variable, haciendo difícil determinar el destino de una ley, cuando ésta limita o expropia un derecho patrimonial. Sin profundizar sobre la diferencia entre regulación y expropiación, presentaremos sentencias de constitucionalidad que parecen variar de una garantía fuerte al derecho de propiedad a otra, que restringe el reconocimiento del derecho en procura de la prevalencia del interés general y la solidaridad. 


\subsection{Las Cesiones Gratuitas obligatorias, escenario de confiscación por el poder legislativo y judicial}

En esta discutible decisión, podemos hallar un desarrollo legislativo y jurisprudencial que excluye el derecho a la expropiación, en caso de cesiones de extensiones físicas de predios privados. La sentencia C-295 de $1993^{38}$ entiende, pese a la elaborada demanda, que en este caso acude a tratados internacionales de derechos humanos ${ }^{39}$, que convienen la obligación de indemnizar toda privación de la propiedad, que el derecho a la propiedad puede ser privado sin el reconocimiento a la indemnización debida. Aunque, no podríamos encontrar en los argumentos de la demanda o de la Corte, mención alguna al Acto Legislativo 01 de 1999 por su estado cronológico, el argumento resulta sorprendentemente idéntico.

En el fallo referenciado, la demanda se dirige contra normas que establecían Cesiones Gra-

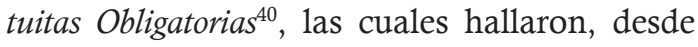

38 Magistrado Ponente: Carlos Gaviria Díaz

39 El argumento de la demanda es la contradicción de la norma acusada con la Convención Americana sobre Derechos Humanos, aprobada por la ley 16 de 1972, que prescribe en su artículo 21: "toda persona tiene derecho al uso y goce de sus bienes", como también que "ninguna persona puede ser privada de sus bienes, excepto mediante el pago de indemnización justa por razones de utilidad pública o de interés social y en los casos y según las formas establecidas por la ley".

40 Los artículos contra los que se dirige la demanda son los $1^{\circ}, 2^{\circ}$ y $7^{\circ}$ de la ley 9 de 1989 que disponen:

Artículo 1o. "Con el objeto de lograr condiciones óptimas para el desarrollo de las ciudades y de sus áreas de influencia en los aspectos físico, económico, social y administrativo, los municipios con una población mayor de cien mil (100.000) habitantes, incluyendo al Distrito Especial de Bogotá, la Intendencia Especial de San Andrés y Providencia y las áreas metropolitanas, deberán formular su respectivo Plan de Desarrollo de conformidad con la política nacional y departamental, las técnicas modernas de planeación urbana y con base en la coordinación del desarrollo urbano-regional.

"Las entidades territoriales a las cuales se refiere el inciso anterior que cuenten con una población de menos de cien mil habitantes (100.000) deberán expedir un Plan de Desarrollo Simplificado que contenga los aspectos contemplados en los numerales 1 y 2 del artículo 34 ." la perspectiva de la Corte, perfecta coherencia con el sistema constitucional e internacional vigente. Su principal argumento señala que, así se aceptara que la propiedad cabe dentro de esa categoría, las normas acusadas no violan la Convención Americana de Derechos humanos, y por el contrario, constituyen pleno desarrollo de sus mandatos, en especial, de lo dispuesto en el artículo 21, que prescribe: "Toda persona tiene derecho al uso y goce de sus bienes. La ley puede subordinar tal uso y goce al interés social", y las cesiones obligatorias gratuitas obedecen precisamente a ese interés público o social por razones de urbanismo y planeación.

En efecto, para la Corte no hay duda de que en virtud de su función social urbanística, la propiedad está sometida a una serie de limitaciones legales que afectan básicamente su uso, dentro de las cuales se encuentran las denominadas cesiones obligatorias gratuitas.

\footnotetext{
"Artículo 2o. Los Planes de Desarrollo incluirán los siguientes aspectos:

"1. Un plan y un reglamento de usos del suelo y cesiones obligatorias gratuitas, así como normas urbanísticas específicas;"

(...)

Artículo 7o. Los municipios y la intendencia Especial de San Andrés y Providencia podrán crear, de acuerdo con su organización legal, entidades que serán responsables de administrar, desarrollar, mantener y apoyar financieramente el Espacio Público, el patrimonio inmobiliario y las áreas de cesión obligatoria para vías, zonas verdes y servicios comunales. Asimismo, podrán contratar con entidades privadas la administración, mantenimiento y aprovechamiento económico de los bienes anteriores.

"Cuando las áreas de cesión para zonas verdes y servicios comunales sean inferiores a las mínimas exigidas por las normas urbanísticas, o cuando su ubicación sea inconveniente para la ciudad, se podrá compensar la obligación de cesión, en dinero o en otros inmuebles, en los términos que reglamenten los Concejos, el Consejo Intendencial y las Juntas Metropolitanas. Si la compensación es en dinero, se deberá asignar su valor a los mismos fines en lugares apropiados según lo determine el Plan de Desarrollo o Plan de Desarrollo Simplificado. Si la compensación se satisface mediante otro inmueble, también deberá estar ubicado en un lugar apropiado según lo determine el mismo plan"

"Los aislamientos laterales, parámetros y retrocesos de las edificaciones no podrán ser compensados en dinero ni canjeados por otros inmuebles".
} 
Para la Corte Constitucional, resultó entonces "claro" que las regulaciones urbanísticas cumplen una función social y ecológica, debido a que tienen como propósito la ordenación y planificación del desarrollo urbano y el crecimiento armónico de las ciudades. De manera que en un ejercicio de ponderación, ha cedido el derecho de propiedad frente al bienestar general.

Este argumento no es fácilmente debatible, pero olvida el Tribunal que la ampliación del interés general sobre el derecho de propiedad resulta discutible toda vez que la Corte no intentó explorar el problema de la expropiación sin indemnización, al contrario, su argumento giró alrededor del interés de la comunidad y el crecimiento "armónico" de las ciudades, olvidando el argumento central de la demanda y de esta discusión. La privación de la propiedad, sea parcial o total, supone la indemnización por concepto del detrimento patrimonial sufrido, el interés general obliga al particular a ceder el derecho, siempre que éste sea protegido por la indemnización.

Con todo, la discusión sobre el valor constitucional de la Convención Americana de Derechos Humanos se hizo esperar, incluso, la Corte negó su integración al Bloque de constitucionalidad, sosteniendo que "no se refiere a todos los derechos humanos consagrados en los tratados y convenios internacionales en sí mismos y de por sí", sino a éstos cuando tales instrumentos internacionales "prohíben su limitación en los estados de excepción", es decir, que para que tenga lugar la prevalencia o superioridad de los tratados y convenios internacionales en el orden interno, es necesario que se den los dos supuestos a la vez; de una parte, el reconocimiento de un derecho humano, y de la otra que sea de aquellos cuya "limitación se prohíba durante los estados de excepción". De este ejemplo exponemos la clara limitación al juez contencioso administrativo, desde la norma y su examen de constitucionalidad encontramos la seria dificultad para declarar la responsabilidad del legislador.

\subsection{El reconocimiento de la Corte al Juez contencioso administrativo para conocer de controversias por el monto de la in- demnización}

En este espacio, la Corte Constitucional Colombiana reconocería la participación del juez contencioso administrativo para la controversia y posible protección al particular cuando se trate de expropiaciones legislativas. Así, en la sentencia C-059 de $2001^{41}$ nuestra Corte expresa que el pago de una indemnización previa a la expropiación, "en los términos del Pacto de San José de Costa Rica, artículo 21.2 y la jurisprudencia de esta Corporación (sentencia C-379/96) ha de ser justa", lo que significa para el Tribunal, que el valor que se fije como indemnización debe comprender todos aquellos aspectos que restablezcan el patrimonio del individuo por la expropiación. La justicia de la indemnización estará garantizada entonces, desde este desarrollo jurisprudencial, por la intervención del juez, quien determinará no sólo la procedencia de la expropiación sino la objetividad del valor fijado a modo de pago por la decisión expropiatoria.

Significa lo anterior, que el instituto de la expropiación descansa sobre tres pilares fundamentales: i) el principio de legalidad, ii) la efectividad del derecho de defensa y del debido proceso del particular que va a ser expropiado y iii) el pago de una indemnización que no haga de la decisión de la administración un acto confiscatorio,

41 Magistrada Ponente: Martha Victoria Sáchica Méndez, Sentencia que decide la constitucionalidad del artículo 71 de la ley 388 de 1998, el cual dispuso: "Proceso contencioso administrativo. Contra la decisión de expropiación por vía administrativa procede acción especial contencioso administrativa con el fin de obtener su nulidad y el restablecimiento del derecho lesionado, o para controvertir el precio indemnizatorio reconocido, la cual deberá interponerse dentro de los cuatro meses calendario siguientes a la ejecutoria de la respectiva decisión. El proceso a que da lugar dicha acción se someterá a las siguientes reglas particulares: (...)

6. De acuerdo con el artículo 58 de la Constitución Política, en el proceso no podrán controvertirse los motivos de utilidad pública o de interés social, pero sí lo relativo al precio indemnizatorio." 
expresamente prohibido en el artículo 34 de la Constitución.

Esta providencia acude al Acto Legislativo 01 de 1999 para construir la derogación implícita que hizo innecesario un pronunciamiento de la Corte sobre la exequibilidad o no del texto demandado, de forma que confirma en este sentido la construcción del concepto de expropiación, reafirmando en todo momento el derecho a una indemnización previa, que como se vio, no puede restringir la intervención del juez administrativo por motivación pública o de interés general.

En esta sentencia evidenciamos además un giro argumentativo de la Corte Constitucional, acudiendo precisamente al Pacto de San José de Costa Rica para señalar que la indemnización por expropiación debe ser justa, lo que significa que el valor que se fije como indemnización debe comprender todos los aspectos que permitan al particular no soportar lesión alguna en su patrimonio por la expropiación.

\subsection{La reafirmación del derecho a la propie- dad desde el Acto Legislativo 01 de 1999}

Desde una protección al derecho de propiedad, siempre que la expropiación suponga el reconocimiento a la indemnización, encontramos la sentencia C- 158 de $2002^{42}$, la cual toma

42 Magistrado ponente: Alfredo Beltrán Sierra. Sentencia que decide la constitucionalidad de los artículos 98 de la ley 388 de 1997 el cual adicionó el artículo 53 de la Ley $9^{a}$ de 1989, con el siguiente parágrafo:

"Para los efectos de que trata este artículo se presumirá el aprovechamiento de la necesidad de vivienda de los ocupantes, en los casos de inmuebles clasificados en los estratos 1 y 2 de la metodología de estratificación socioeconómica vigente. El alcalde municipal o distrital iniciará directamente el proceso de expropiación por vía administrativa, aplicándose el procedimiento previsto en los artículos 69 y siguientes de la presente ley, siendo, entendido que no habrá lugar a indemnización alguna".

Por su parte, el artículo 53 de la Ley $9^{a}$ de 1989, adicionado con el parágrafo transcrito, prevé la posibilidad de la expropiación sin indemnización por razones de equidad, cuando se presenten los eventos que prescribe la norma. En efecto, señala dicha disposición :

"Para los efectos previstos en el último inciso del artícu- como regla esencial el Acto Legislativo No. 01 de $1999^{43}$, entendiendo que éste suprimió la totalidad del inciso $5^{\circ}$ del artículo 58 constitucional, en el cual, se consagraba la expropiación por razones de equidad sin que hubiera lugar al pago de indemnización, lo que trajo como consecuencia que "cualquier restricción al derecho de propiedad por parte del Estado en razón a la prevalencia del interés general sobre el particular, se encuentra sometida al pago de la indemnización correspondiente".

En este sentir, podemos desprender del artículo 58 , modificado por el acto legislativo mencionado, la restricción a normas que conduzcan a expropiaciones sin que ésta conlleve el reconocimiento de la indemnización, incluso cuando se trate de una decisión legislativa, la cual como lo expresó nuestra Corte, no podría relegarse por motivos de simple interés general. Con todo, esto no ha sido así hasta los años más próximos.

\subsection{La Sentencia C-189 de 2006, legitimación de la expropiación sin indemnización de la Corte Constitucional posterior al A.L. 01 de 1999}

La sentencia C-189 de $2006^{44}$ expone un escenario en el cual el legislador ha limitado cierta-

lo 30 de la Constitución Política declárase que existen motivos de equidad para decretar la expropiación sin indemnización cuando el propietario de un inmueble ubicado en sitio apto o no apto para urbanizar, en contravención a las normas sobre usos del suelo, o fuera del perímetro sanitario y urbano del municipio, del Distrito Especial de Bogotá, de un área metropolitana, de la Intendencia de San Andrés y Providencia, o sin contar con los permisos y licencias requeridos por las leyes, y acuerdos, aprovechándose de la necesidad de vivienda de los ocupantes, venda, prometa en venta, promueva o tolere la ocupación de dicho inmueble para vivienda de interés social...".

43 Reformatorio del Inciso $5^{\circ}$ del artículo 58 de la Constitución, el cual disponía: "Con todo, el legislador, por razones de equidad, podrá determinar los casos en que no haya lugar al pago de indemnización, mediante el voto favorable de la mayoría absoluta de los miembros de una y otra Cámara. Las razones de equidad, así como los motivos de utilidad pública o interés social, invocados por el legislador, no serán controvertibles judicialmente".

44 Magistrado Ponente: Rodrigo Escobar Gil. 
mente el derecho a la propiedad, principalmente, el atributo de disposición sobre los bienes inmuebles que se encuentren en zonas declaradas como parte de los Parques Nacionales. La norma debatida era el artículo 13 de la ley $2^{\mathrm{a}}$ de 1959, que declaraba Parques Nacionales Naturales a aquellas zonas que el Gobierno Nacional, por intermedio del Ministerio de Agricultura, previo concepto favorable de la Academia Colombiana de Ciencias Exactas, Físicas y Naturales, delimite y reserve de manera especial, por medio de Decretos, en las distintas zonas del país y en sus distintos pisos térmicos, y en las cuales, quedó prohibida la adjudicación de baldíos, las ventas de tierras, la caza, la pesca, y toda actividad industrial, ganadera o agrícola, distinta a la del turismo o a aquellas que el Gobierno Nacional considera convenientes para la conservación o embellecimiento de la zona.

Debemos hacer una breve aclaración respecto a la divergencia entre los actos administrativos, en este caso, decretos que declaren qué zonas consideraría parte del Parque Natural, y la ley, como hechos dañosos que son imputables sólo en la medida en que la ley es la principal causante del daño. La composición de la disposición examinada conduce a la atribución directa de responsabilidad por expropiación al legislador, por cuanto la norma por él expedida conduce a la ineludible reparación de un perjuicio patrimonial causado.

La Corte afirma en el examen de constitucionalidad de esta ley, el Sistema de Parques Nacionales Naturales se convierte en un límite al ejercicio del derecho a la propiedad privada, en cuanto a que las áreas que se reservan y declaran para tal fin, comprenden tanto terrenos de propiedad estatal, como de propiedad particular. En estos casos, los propietarios de los inmuebles afectados por dicho gravamen, "deben allanarse por completo al cumplimiento de las finalidades del sistema de parques y a las actividades permitidas en dichas áreas de acuerdo al tipo de protección ecológica que se pretenda realizar".

Esto permitió sostener al Tribunal Constitucional que no se desconoce el núcleo esencial del derecho a la propiedad cuando se imponen por el legislador prohibiciones temporales de enajenación o limitaciones intemporales o por extensos períodos de tiempo, siempre y cuando, dichas medidas, además de preservar un interés superior, mantienen indemne los atributos de goce, uso y explotación que "le permitan a su titular -de acuerdo con las limitaciones previstas en el ordenamiento jurídico- obtener algún tipo de utilidad económica que justifique la presencia de un interés privado en la propiedad".

La Corte presenta entonces un argumento bastante controvertible cuando afirma que las limitaciones a la enajenación de los bienes privados "no implican el desconocimiento del núcleo esencial del citado derecho, porque además de preservar sobre ellos los atributos de goce, uso y explotación, responden a la necesidad de asegurar un interés superior que goza de prioridad en aras de salvaguardar los fines del Estado Social de Derecho", "lo que establece es una restricción para llevar a cabo la enajenación a través del instituto de la compraventa, de todo tipo de bienes que se encuentren ubicados en las zonas correspondientes al Sistema de Parques Nacionales Naturales, en la medida en que la ley no distingue la clase de propiedad frente a la cual procede dicha prohibición".

Entonces, para el Tribunal resulta conforme a la Carta Fundamental la norma demandada en el sentido en el que no se vulnera el núcleo esencial del derecho por varias razones. Primero, porque la restricción obedece a un interés general legítimo, segundo, porque la función ecológica le es inherente al derecho de propiedad, y tercero, porque su explotación económica indiscriminada derivada de la colonización agrícola amenaza destruir gran parte de la diversidad de la flora y fauna colombiana.

Los argumentos señalados por la Corte son innegables. La riqueza de los recursos ambientales de nuestro país requiere especial atención, en mayor medida, cuando estamos frente a un derecho que tiene una función ecológica como es la propiedad privada. Sin embargo, el punto no es resuelto exitosamente, porque en realidad estamos ante un 
escenario de expropiación. El interés general que reviste la medida legislativa mencionada ha sido demostrado por la Corte, pero el punto relativo a la indemnización justa que exige la Constitución es omitido por completo.

En este sentido, el argumento es inconcluso y no representa realmente una explicación adecuada de la privación a un derecho individual. La imposibilidad de enajenar un predio no supone otra cosa que la expropiación del mismo, con mayor razón, si además de esta imposición, no es posible darle otros destinos diferentes que el turístico. En esencia, propiedad privada supone siempre la posibilidad de trasladarla a otros sujetos de derecho, sin que su función ecológica tenga alguna relevancia evidente al respecto, hecho que supondría además la desproporción de la medida.

El profesor Gustavo Quintero parecería sostener en ese evento, que las normas ambientales, al momento de generar un perjuicio anormal y especial cobijado por una norma constitucional, con mayor razón cuando su fundamento obedece a la protección al medio ambiente, permitirían acudir al juez administrativo por medio del régimen del rompimiento de las cargas públicas, por cuanto la falla del servicio legislativo estaría descartada. La vía judicial parecería ser la nulidad y restablecimiento del derecho en cuanto se trata realmente de una verdadera acción en reparación porque el artículo 85 del Código Contencioso Administrativo ${ }^{45}$, prevé la posibilidad de solicitar al juez el resarcimiento de los daños causados como consecuencia de la nulidad, o incluso, sin necesidad de ella ${ }^{46}$.

$45 \quad$ El artículo citado dispone: "Toda persona que se crea lesionada en un derecho amparado en una norma jurídica, podrá pedir que se declare la nulidad del acto administrativo y se le restablezca en su derecho; también podrá solicitar que se le repare el daño. La misma acción tendrá quien pretenda que le modifiquen una obligación fiscal, o de otra clase, o la devolución de lo que pago indebidamente" (Negrilla fuera de texto).

46 QUINTERO NAVAS, Gustavo. Regímenes de responsabilidad del Estado por el menoscabo causado a la propiedad privada con el fin de proteger el medio ambiente: Perspectiva francesa y colombiana a partir de la ponencia del profesor René Hostiou, Revista de Derecho Público No. 11, Junio de 2000, Universidad de los Andes. p. 148.
No obstante, el Consejo de Estado ha sostenido que el daño que se puede causar por un acto administrativo legal, no puede reclamarse a través de la acción de nulidad y restablecimiento del derecho, debido a que el restablecimiento del derecho en ésta tiene, por el contrario, fundamento exclusivo en la inconstitucionalidad o ilegalidad del acto. Tal pretensión solamente podría deducirse ante esta jurisdicción mediante la acción de reparación directa en la modalidad de responsabilidad extracontractual del Estado por daño especial ${ }^{47}$.

Del mismo modo, ha señalado el Consejo de Estado, para que podamos identificar un espacio próspero para alcanzar la indemnización debida mediante la acción de reparación directa, se necesita que el acto administrativo sea legal, esto es, que se trate de una actuación legítima de la administración, y que se acredite que la carga impuesta al administrado es "anormal o desmesurada (rompimiento de la igualdad ante

47 Ver Consejo de Estado, Sentencia del 8 de marzo de 2007, Sala de lo Contencioso Administrativo, Sección III, M.P. Ruth Stella Correa, Radicación número: 66001233100003613-01 (16421), Actor: Carlos Sammy López Mustafá, Demandado: Municipio de la Virginia y Otro. Cita las siguientes sentencias: Consejo de Estado, Sala de lo Contencioso Administrativo, Sección I, Sentencia de 21 de marzo de 1996, Rad. 3575, Actor: Sociedad Las Mercedes Ltda. Sucesores y Cía. S. En C. S.,C. P. Ernesto Rafael Ariza Muñoz. Criterio reiterado en Sección I, Sentencia de 28 de noviembre de 1996, Rad. 3967, Actor: Hacienda Villa Lucía Limitada Martha Patricia Ramírez Nieto, C. P. Libardo Rodríguez Rodríguez; Sección I, Sentencia de 8 de mayo de 1997, Exp. 4291, Actor: Kokoriko Ltda., C. P. Juan Alberto Polo Figueroa; Sección I, Sentencia de 8 de mayo de 1997, Rad. 4208, Actor: Sociedad Operaciones Bursátiles S.A., Demandado: Concejo Municipal de Santiago de Cali, C. P. Juan Alberto Polo Figueroa; Sección I, Sentencia de 22 de mayo de 1997, Exp. 4261, Actor: Antonio Obeso de Mendiola y Otra, C. P. Ernesto Rafael Ariza Muñoz y Sección I, Sentencia de 22 de mayo de 1997, Rad. 4207, Actor: Sociedad Las Mercedes Ltda. Hermanos y Cía. S. en C.S., Demandado: Concejo Municipal de Santiago de Cali, C.P. Libardo Rodríguez Rodríguez; Sección I, Sentencia de 22 de mayo de 1.997, Rad. 4205, Actor: Yolanda Velasco de Navia y otros, Demandado: Concejo Municipal de Santiago de Cali, C.P. Ernesto Rafael Ariza Muñoz. 
las cargas públicas o violación de la justicia distributiva)" ${ }^{48}$.

En consecuencia, sea mediante la acción de plena jurisdicción o la acción de reparación directa, el reconocimiento a la indemnización debida al individuo por esta decisión legislativa es innegable. La Corte prueba que efectivamente, el interés general es un supuesto que la norma acusada garantiza, pero esta es sólo una parte del escenario expropiatorio que supone la ley $2^{\mathrm{a}}$ de 1959.

\section{LA PARTICIPACIÓN DEL JUEZ ADMINISTRATIVO EN EL PROCESO DIALÓGICO}

Para nuestra disertación, el proceso dialógico cobra especial importancia cuando intentamos legitimar la intervención del Juez Administrativo, al declarar la responsabilidad del Legislador, sea por su voluntad implícita o explícita de impedir tal reconocimiento, para así, exponer el despliegue de una decisión judicial que participa de la configuración del sistema jurídico.

Una primera aproximación al tema desde la doctrina española, aparece cuando se postula la "contradicción contramayoritaria", propuesta que reprocha toda decisión del juez más allá de la norma legislada, pues al intervenir en el conocimiento de constitucionalidad de una norma, "tuerce la voluntad de los representantes del pueblo", de modo que ejerce el control no en nombre de la mayoría, sino en su contra ${ }^{49}$.

La réplica propuesta en este punto consistirá en presentar al control judicial como el mecanismo adecuado para la protección de libertades civiles y derechos fundamentales, manteniendo a los ciudadanos a salvo de toda intervención

48 Consejo de Estado, Sentencia del 8 de marzo de 2007, Sala de lo Contencioso Administrativo, Sección III, M.P. Ruth Stella Correa, Radicación número: 6600123310000361301 (16421), Actor: Carlos Sammy López Mustafá, Demandado: Municipio de la Virginia y Otro.

49 BICKEL, A. The Least Dangerous Branco, New Haven; Yale University Press, Citado por MENDONCA Daniel y GUIBOURG Ricardo, Op. Cit. p. 150. del poder apartada de los límites constitucionales, con el objetivo de defender la supremacía de la Constitución ${ }^{50}$.

En este sentido, el concepto de proceso dialógico, desde la perspectiva del activismo judicial exigible del juez Administrativo, abre el reconocimiento de la reparación de un patrimonio particular afectado por una decisión legislativa, implicando su participación en la estructuración del ordenamiento jurídico y sobre todo, le permite convertirse en un instrumento que enriquezca la misma democracia. Por esta razón, el profesor Gargarella ${ }^{51}$ sugiere que la revisión judicial puede ser instrumento crucial para enriquecer las deliberaciones públicas respecto a los derechos sociales y por qué no, fundamentales ${ }^{52}$.

Gargarella considera que no existe una buena razón para pensar que la intervención judicial en esta área se encuentre en conflicto con la democracia deliberativa. Por el contrario, el juez decide de forma "muy respetuosa" hacia la autoridad superior del pueblo y de sus representantes $^{53}$. De esta manera, la verificación de un derecho violado permite solicitar al juez medios para exigir su reparación.

Nuestro supuesto, como lo mencionamos anteriormente de forma importante en las leyes expropiatorias, no consiste en la revisión judicial del contenido de una ley ni de su validez, pues ésta corresponde únicamente a la Corte Constitucional. La revisión que tratamos en este punto consiste en los efectos de la misma, generadores de perjuicios concretos y verificables, los cuales desde la Constitución, conducen al reconocimiento de una indemnización.

50 MENDONCA, Daniel y GUIBOURG, Ricardo. La Odisea Constitucional, Ed. Marcial Pons, Ediciones jurídicas y sociales, Madrid 2004., p. 150.

51 GARGARELLA, Roberto. Crisis de la Representación Politica, Ed. Biblioteca de ética, filosofía del derecho y política, México 1997. p. 30 y ss.

52 Sobre este punto, el autor referenciado cita a COHEN J. The economic Basis of Deliberative Democracy, en Social Philosophy and Policy, Vol. 6 1989. p. 25-50.

53 GARGARELLA, Roberto. ¿Democracia deliberativa $y$ judicialización de los derechos sociales? Op. Cit. 
Por tanto, consideramos pertinente la introducción del concepto de la democracia deliberativa, razonando a la misma, como aquella que no excluye la revisión judicial como posible arreglo institucional, la cual podría conducir a una "razonable" disputa sobre el alcance de la misma, pero siempre arrojando como resultado, nuevas "observaciones filosóficas o evidencia empírica" ${ }^{54}$.

Así, armonizamos desde la jurisdicción contenciosa administrativa, la voluntad legislativa y del juez constitucional, la concepción de una estructura estatal que implica la aceptación de un "orden de valores a proteger que son precisamente los que dan sentido al constitucionalismo moderno" 55 , de forma tal que del interés público no tiene que derivarse el necesario sacrificio del interés privado, pues ambos resultarían compatibles. Ésta armonización se "logra de modo principal mediante mecanismos de la expropiación forzosa y la reparación de los daños por medio de su indemnización" ${ }^{56}$.

Desde la experiencia Estadounidense, la revisión judicial (para nuestro punto, la complementación o corrección de la norma sin afectación a su validez), asegura a la sociedad "no sólo contra la opresión de sus gobernantes, sino que también protege a una parte de la sociedad contra las injusticias de la otra" ${ }^{27}$.

De esta manera, la vulneración de derechos particulares estará sujeta a la verificación en cada caso concreto. No obstante, la motivación general a la intervención del juez administrativo para la reparación del particular encuentra justificación desde el despliegue de elementos constitucionales como los señalados anteriormente, que tienen por efecto, la protección de derechos

54 TOMPSON, D. Democratic Theory and Global society, en Journal of Political Philosophy 09638016, junio vol. 7 núm 2. Citado por GARGARELLA Roberto, Op. Cit.

55 ACOSTA Gallo, Pablo. Op. Cit. p. 48.

56 Ibidem.

57 BLANCO VALDES, Roberto. El Estado social y el derecho politico de los norteamericanos, en Modelos constitucionales en la historia comparada, Universidad de Oviedo, Oviedo 2005. p. 103. patrimoniales privados respecto de decisiones mayoritarias que le pueden resultar lesivas.

Entonces, los Tribunales resultan especialmente efectivos, desde la filosofía política norteamericana, para corregir los extravíos de la democracia y "sin poder detener nunca los movimientos de la mayoría, consiguen frenarlos y dirigirlos" 58 . Hamilton explicará la funcionalidad constitucional del poder judicial, salvando cualquier intención de entender como superior el poder judicial de cualquier otro, sosteniendo que la revisión "sólo supone que el poder del pueblo es superior a ambos [judicial y legislativo] y que donde la voluntad de la legislatura declarada en las leyes, entra en contradicción con la del pueblo, declarada en la Constitución, los jueces deberán conformarse a la última de las preferencias y no a las primeras. Deberán regular sus decisiones por las leyes fundamentales y no por las que no tienen ese carácter fundamental" ${ }^{\prime \prime}$.

La doctrina alemana parecería aportar un interesante paradigma cuando señala a la Constitución como fuente primaria de toda decisión de cualquier poder público. La Carta declara vinculantes conquistas elementales de la cultura jurídica y contiene la promesa de constituir al Estado vinculándolo a valores probados y a la experiencia política acreditada. Tal propósito sujeta al Estado, que no puede discrecionalmente reformar o derogar la Constitución. En efecto, la atribución de poder político o económico requiere de una decisión del legislador. "Pero los derechos inviolables e inalienables del hombre como fundamento de toda comunidad humana (artículo 1.2 Ley Fundamental) encierran una pretensión de universalidad y quieren ser presupuesto vinculante para todas las constituciones de la tierra"60.

58 Ibidem, p. 111.

59 HAMILTON, Alexander. E1 federalista, p. 467-468 contenida en los números 67, 68 y 69, Citado por BLANCO VALDES, Roberto. Op. Cit. p. 117.

60 KIRCHHOF, Paul. Tareas del bundesverfassungsgericht en una época de cambios, Revista Española de Derecho Constitucional, Año 17. Núm. 49. Enero-Abril 1997. 
De estas palabras deducimos el papel preordenante de la Constitución, que pese a considerar obvia, resulta de especial trascendencia al momento de legitimar la actividad judicial del Tribunal administrativo abocado a la garantía y desarrollo de mandatos de un poder constituyente que parecería altamente democrático, con mayor intensidad tratándose de la experiencia constitucional colombiana de 1991.

Asimismo, como se mencionó con anterioridad, la intervención del Juez administrativo procurará no la revisión de la voluntad legislativa o de la interpretación realizada por la Corte Constitucional, sino que logrará expandir el régimen de responsabilidad del Estado, desde bases concretas del caso, desplegando principios constitucionales que dirigen la actividad del Estado y su intervención en la economía con el fin de procurar la protección a patrimonios particulares afectados.

De esta forma, el proceso dialógico se cierra, de manera que el particular encuentra asidero a la protección constitucional e internacional de sus derechos patrimoniales, enriqueciendo el debate democrático y deliberativo en un sentido garantista, siendo protegido de decisiones mayoritarias excesivas y especiales, que a su vez, procuran el desenvolvimiento de normas constitucionales.

\section{CONCLUSIÓN}

El Tribunal Contencioso Administrativo es el único juez competente para conocer de la responsabilidad del Estado y de la Acción de Reparación directa, evento reconocido por la Corte Constitucional colombiana en sentencia C-038 de 2006 en el caso concreto de la responsabilidad del Estado Legislador, lo que legitima cualquier imputación de responsabilidad al Legislador aún cuando éste exprese oposición a la indemnización o al precio justo en el evento expropiatorio, lo que supone siempre la competencia exclusiva para conocer de la reparación directa.

En el evento en el que el Legislador ha decidido excluir la indemnización por vía de expropiación, excepto en el "daño merecido", hemos encontrado que la institución efectiva que salva la legitimidad del juez administrativo será la mencionada competencia exclusiva en la reparación de daños causados con ocasión a la aplicación de una norma, legitimidad que sobrevive pese a la intervención de la Corte Constitucional, este entendido desde la reparación bajo el régimen del rompimiento de la igualdad ante las cargas públicas.

Finalmente, de la participación del Consejo de Estado colombiano en el proceso dialógico podríamos esperar la proyección de decisiones que supongan el desarrollo y extensión de principios constitucionales en la participación conjunta del desarrollo del sistema jurídico garantista y democrático, donde la distribución institucional de competencias supone la abierta configuración colectiva y legitimadora del ordenamiento jurídico.

Así, la norma que dirige las conductas sociales resulta altamente estructurada y a toda luz, protectora de derechos e intereses privados, que como vimos anteriormente, no se opone a la realización del interés general, debiendo en todo caso respetar la debida reparación patrimonial a daños antijurídicos y el derecho a la propiedad.

\section{BIBLIOGRAFÍA}

ACOSTA GALLO, Pablo. La Responsabilidad del Estado-Juez, Ed. Montecuervo S.A. Madrid 2005.

BLANCO VALDES, Roberto. El Estado social y el derecho político de los norteamericanos, en Modelos constitucionales en la historia comparada, Universidad de Oviedo, Oviedo 2005.

BROYELLE, Camilla. La responsabilité de L'état du fait des lois, Librairie Générale de Droit et de Jurisprudence, Bibliothèque de droit Public Tome 236, 2003.

Consejo de Estado, Sentencia del 8 de marzo de 2007, Sala de lo Contencioso Administrativo, Sección III, M.P. Ruth Stella Correa, Radicación número: 66001233100003613-01 (16421), 
Actor: Carlos Sammy López Mustafá, Demandado: Municipio de la Virginia y Otro.

Corte Constitucional Colombiana. Sentencia C-245 de 1994.

DUGUIT León. Manual de derecho constitucional: teoría general del Estado, el derecho y el Estado, las libertades públicas, organización pública. Traducción por José G. Acuña. 2a . Ed. Madrid 1926.

FERNÁNDEZ Tomás-Ramón. De la Arbitrariedad del Legislador, una crítica de la jurisprudencia Constitucional. Ed. Civitas Madrid 1998, p. 41 y ss.

GALÁN VIOQUE Roberto. De la teoría a la realidad de la responsabilidad del Estado legislador. Revista de Administración Pública Núm. 155. Mayo-agosto 2001.

GARCÍA ÁlVAREZ G. La Responsabilidad Patrimonial de los Poderes Públicos, en Derecho Administrativo, Parte Especial, Ed. Civitas, Madrid 1994.

GARCÍA DE ENTERRÍA Eduardo. La Responsabilidad Patrimonial del Estado Legislador en el Derecho Español. Ed. Thomson Civitas, Madrid 2005.

GARCÍA DE ENTERRÍA Eduardo. Democracia, jueces y control de la Administración. $5^{\mathrm{a}} \mathrm{Ed}$. Civitas, Madrid 2000, p. 211. cita a J- GUASP Aragoneses, Derecho Procesal Civil, Tomo I. $5^{\text {a }}$ Ed. Civitas, Madrid 2002.

GARCÍA SOLANO José Eugenio. Responsabilidad patrimonial del Estado legislador y el proceso descolonizador. REDA num 30 de 1981.

GARGARELLA Roberto. Crisis de la Representación Politica. Ed. Biblioteca de ética, filosofía del derecho y política, México 1997.

HERNÁNDEZ VALLE Rubén. La tipología de las sentencias constitucionales con efectos fiscales.
Revista Española de Derecho Constitucional, Año 14. Núm. 41. Mayo-Agosto 1994.

JIMÉNEZ LECHUGA Francisco Javier. La responsabilidad patrimonial de los poderes públicos en el derecho español. Marcial Pons, Ed. Jurídica y social, Madrid 1999.

KIRCHHOF Paul. Tareas del bundesverfassungsgericht en una época de cambios, Revista Española de Derecho Constitucional. Año 17. Núm. 49. Enero-Abril 1997.

MENDONCA Daniel y GUIBOURG Ricardo. La Odisea Constitucional. Ed. Marcial Pons, Ediciones jurídicas y sociales, Madrid 2004.

QUINTANA LÓPEZ Tomas. La responsabilidad del Estado legislador, Revista de Administración Pública. Num. 135, septiembre-diciembre 1994.

QUINTERO NAVAS Gustavo. Regímenes de responsabilidad del Estado por el menoscabo causado a la propiedad privada con el fin de proteger el medio ambiente: Perspectiva francesa y colombiana a partir de la ponencia del profesor René Hostiou. Revista de Derecho Público No. 11, Junio de 2000, Universidad de los Andes.

SALAS Javier. El tribunal constitucional español y su competencia desde la perspectiva de la forma de gobierno: sus relaciones con los poderes legislativo, ejecutivo y judicial. Revista Española de Derecho Constitucional. Abril 2. Núm. 6. Septiembrediciembre 1982.

SANTAMARÍA PASTOR Juan Alfonso. $\mathrm{La}$ teoría de la responsabilidad del Estado legislador. Revista de Administración Pública, Num. 68, Mayo-Agosto de 1972.

Sentencias del Tribunal Constitucional Español: STC del 20 de julio de 1981, STC del 19 de julio de 1982, STC del 23 de mayo de 1985, STC del 29 de julio de 1986, STC del 11 de junio de 1987, STC del 22 de marzo de 1988, STC del 29 de Noviembre de 1988, STC del 22 de Abril de 1993, STC del 22 de junio de 1993. 